\title{
DOSES AND SPLIT NITROGEN FERTILIZER APPLICATIONS ON THE PRODUCTIVITY AND QUALITY OF ARUGULA ${ }^{1}$
}

\author{
CAMILA SENO NASCIMENTO² ${ }^{2}$ CAROLINA SENO NASCIMENTO² ${ }^{2}$ ARTHUR BERNARDES CECÍLIO FILHO ${ }^{2 *}$
}

\begin{abstract}
Splitting nitrogen $(\mathrm{N})$ fertilizer application can be an efficient nutrient management technique to improve productivity and plant quality, as well as to reduce the negative environmental impact caused by $\mathrm{N}$ losses. In this context, the present study investigated how the management of $\mathrm{N}$ affects the agronomic characteristics of field-grown arugula plants. Nine treatments were assessed in a randomized complete block design, in a $4 \times 2+1$ factorial scheme, with three replicates. The evaluated factors were doses of $\mathrm{N}(60,120$, 180 and $240 \mathrm{~kg} \mathrm{~N} \mathrm{ha}^{-1}$ ), split $\mathrm{N}$ fertilizer applications at side-dress (two and three times) and an additional treatment without a $\mathrm{N}$ supply. Maximum height was obtained with the application of $198 \mathrm{~kg} \mathrm{~N} \mathrm{ha}^{-1}$. Nitrate content, fresh mass and productivity increased with increasing $\mathrm{N}$ doses. There was no effect of split $\mathrm{N}$ fertilizer applications on the characteristics evaluated. Therefore, the supply of $240 \mathrm{~kg} \mathrm{~N} \mathrm{ha}^{-1}$ divided into two portions was considered as the best management strategy.
\end{abstract}

Keywords: Eruca sativa. Nitrate. Mineral nutrition.

\section{DOSES E PARCELAMENTO DA ADUBAÇÃO NITROGENADA NA PRODUTIVIDADE E QUALIDADE DA RÚCULA}

RESUMO - O parcelamaneto da adubação nitrogenada pode ser uma estratégia eficiente de gerenciamento nutricional para melhorar a produtividade, qualidade das plantas e reduzir o impacto ambiental negativo causado pelas perdas de nitrogênio (N).Nesse contexto, o presente estudo investigou o efeito do manejo de $\mathrm{N}$ nas características agronômicas de plantas de rúcula cultivadas em campo. Foram avaliados nove tratamentos, em delineamento experimental de blocos ao acaso, em esquema fatorial 4 x $2+1$, com três repetições. Os fatores avaliados foram doses de $\mathrm{N}\left(60,120,180\right.$ e $\left.240 \mathrm{~kg} \mathrm{ha}^{-1} \mathrm{de} \mathrm{N}\right)$, parcelamento da adubação nitrogenada em cobertura (duas e três vezes) e um tratamento adicional sem a aplicação de N. Máxima altura foi obtida com a aplicação de $198 \mathrm{~kg} \mathrm{ha}^{-1}$ de $\mathrm{N}$. O aumento das doses de $\mathrm{N}$ promoveu o aumento do teor de nitrato, da massa fresca e da produtividade da rúcula. Não houve efeito do parcelamento da adubação nitrogenada em cobertura nas características avaliadas. Assim, o fornecimento de $240 \mathrm{~kg} \mathrm{ha}^{-1}$ de $\mathrm{N}$, aplicado em duas parcelas foi considerado como o melhor manejo.

Palavras-chave: Eruca sativa. Nitrato. Nutrição mineral.

\footnotetext{
${ }^{*}$ Corresponding author

${ }^{1}$ Received for publication in 10/23/2020; accepted in 07/19/2021.

${ }^{2}$ Department of Plant Production, Universidade Estadual Paulista, Jaboticabal, SP, Brazil; camilaseno@gmail.com - ORCID: 0000-00032558-5765, senocarolina@gmail.com - ORCID: 0000-0002-8096-5392, arthur.cecilio@unesp.br - ORCID: 0000-0002-6706-5496.
} 


\section{INTRODUCTION}

Arugula (Eruca sativa) is an economically important leafy green that has been gaining prominence in the vegetable group for being a phytonutrient-rich food (JASPER; WAGSTAFF; BELL, 2020). As it is a crop with a short cycle, it demands a high concentration of nutrients in a short period. However, so far, studies related to the nutritional management of this crop are scarce, especially regarding methods to increase nitrogen (N) fertilization efficiency, a factor that represents approximately $16.6 \%$ of the total operating cost (NASCIMENTO; NASCIMENTO; CECÍLIO FILHO, 2018).

$\mathrm{N}$ is the second most required nutrient for arugula (MORAIS et al., 2020). Its presence is essential for plant development because it contributes directly to the chlorophyll content, photosynthesis and vegetative growth (MEN et al., 2020). When $\mathrm{N}$ is applied in insufficient doses, it limits the productivity and development of plants. On the other hand, when it is applied in excess, it can cause agronomic, environmental and economic problems, in addition to health threats (ANJANA; UMAR, 2017).

The negative impact of $\mathrm{N}$ on human health is due to the ingestion of foods containing high nitrate concentrations. Arugula, like other leafy greens, is considered a nitrate hyperaccumulating species (SCHIATTONE et al., 2018). This element is responsible for causing harmful effects on human health, such as methemoglobinemia (MetHba), and for being a precursor to carcinogenic compounds such as nitrosamines (SANTAMARIA; ELIA, 1997). It is known that, in addition to the genotype and environmental conditions (BONASIA et al., 2017), the application of $\mathrm{N}$ fertilizers has a close relationship with the accumulation of nitrate in the arugula crop. Indeed, when nitrate absorption exceeds assimilation by the plant, nitrate accumulates in plant tissues (WEIGHTMAN et al., 2012, COLLA et al., 2018). So, improved techniques that can be used to maximize the agronomic performance of arugula and minimize the accumulation of nitrate in this vegetable are urgently needed. Among the several approaches that can be used to achieved this goal, the establishment of a tactical fertilization program capable of supplying $\mathrm{N}$ in quantities and at times that approximately match the nutrient demands of arugula plants is an efficient, lucrative and environmentally friendly strategy for farmers (KABIR et al., 2021). Splitting the total N dose into two or more portions possibly synchronizes the $\mathrm{N}$ supply with the capacity of plants to utilize the nutrient more efficiently, improving $\mathrm{N}$ use efficiency, productivity and plant quality, as well as reducing the costs and negative environmental impact of $\mathrm{N}$ losses.

To this end, this work was carried out to evaluate the effect of $\mathrm{N}$ on the arugula crop and its effect on the growth, productivity and quality of plants.

\section{MATERIAL AND METHODS}

The experiment was conducted in the field from 11 January to 21 February 2008 at São Paulo State University (UNESP), campus Jaboticabal, São Paulo, Brazil $\left(21^{\circ} 15^{\prime} 22^{\prime \prime} \mathrm{S}, 48^{\circ} 15^{\prime} 58^{\prime \prime} \mathrm{W}\right.$, $575 \mathrm{~m}$ a.s.1.). The total rainfall and mean daily maximum, mean daily minimum and average daily temperatures during the experimental period were $437.8 \mathrm{~mm}, \quad 29.3{ }^{\circ} \mathrm{C}, \quad 19.8{ }^{\circ} \mathrm{C}$ and $23.5{ }^{\circ} \mathrm{C}$, respectively.

The soil in the experimental area is a typical Rhodic Eutrudox with a very clayey texture (SANTOS et al., 2018). Chemical analysis of the soil prior to the experiment indicated a $\mathrm{pH}\left(\mathrm{CaCl}_{2}\right)$ of 5.5 , $19.0 \mathrm{~g} \mathrm{dm}^{-3}$ of organic matter, $93 \mathrm{mg} \mathrm{dm}^{-3}$ of $\mathrm{P}$ (resin), $2.6 \mathrm{mmol}_{\mathrm{c}} \mathrm{dm}^{-3}$ of $\mathrm{K}, 34.0 \mathrm{mmol}_{\mathrm{c}} \mathrm{dm}^{-3}$ of $\mathrm{Ca}$, $13 \mathrm{mmol}_{\mathrm{c}} \mathrm{dm}^{-3}$ of $\mathrm{Mg}, 28.0 \mathrm{mmol}_{\mathrm{c}} \mathrm{dm}^{-3}$ of $\mathrm{H}+\mathrm{Al}$, $77.6 \mathrm{mmol}_{\mathrm{c}} \mathrm{dm}^{-3}$ cation exchange capacity and $64 \%$ base saturation of the soil.

Nine treatments were evaluated in a randomized complete block design, in a $4 \times 2+1$ factorial scheme, with three replicates. The evaluated factors were $\mathrm{N}$ doses $(60,120,180$ and $240 \mathrm{~kg} \mathrm{~N} \mathrm{ha}^{-1}$ ) applied as ammonium nitrate (34\%), split $\mathrm{N}$ fertilizer applications at the side-dress (two and three times) and an additional treatment without a $\mathrm{N}$ supply. The $\mathrm{N}$ sidedress applications were carried out at 7 and 14 days after the emergence (DAE) of arugula seedlings and at 7, 14, and 21 DAE for applications divided into two and three applications, respectively. Twenty-five percent of the total $\mathrm{N}$ amount established in the treatments was applied at planting, and $75 \%$ was divided and supplied at side-dress in portions and at the times established in the treatments. The fertilizer was distributed along the rows, about $3 \mathrm{~cm}$ apart. The experimental unit had a total area of $2 \mathrm{~m}^{2}(1.0 \mathrm{~m}$ wide by $2.0 \mathrm{~m}$ long), containing eight rows, with spacing between rows of $0.25 \mathrm{~m}$ and $0.05 \mathrm{~cm}$ between plants within the row. The useful area for data collection corresponded to the four central rows $\left(1 \mathrm{~m}^{2}\right)$.

The soil was prepared by plowing and harrowing before the construction of beds. Calcined lime $(48 \% \mathrm{CaO}$ and $16 \% \mathrm{MgO})$ with a relative total neutralization power of $125 \%$ was added 30 days before planting to increase the base saturation of the soil to $80 \%$ (TRANI; PASSOS; AND AZEVEDO FILHO, 1997). The arugula cultivar 'Folha Larga' was sown directly on the bed, and thinning was carried out at $12 \mathrm{DAE}$ to adjust the spacing between plants. At planting, $100 \mathrm{~kg} \mathrm{~K}_{2} \mathrm{O} \mathrm{ha}{ }^{-1}$ (potassium chloride) and $200 \quad \mathrm{~kg} \quad \mathrm{P}_{2} \mathrm{O}_{5} \quad \mathrm{ha}^{-1}$ (simple superphosphate) were applied as recommended by 
Trani, Passos and Azevedo Filho (1997).The crop was irrigated by a sprinkler at a rate of $5 \mathrm{~mm} \mathrm{~d}^{-1}$. Weeds were controlled by manual hoeing. The harvest was carried out at 42 DAE.

For the assessment of the nutritional status of arugula, the $\mathrm{N}$ content $\left(\mathrm{g} \mathrm{kg}^{-1}\right)$ was determined in the newly developed leaves (two per plant) at 23 DAE. The leaves were washed, dried, ground and prepared for the determination of $\mathrm{N}$, according to the methodology proposed by Miyazawa et al. (2009). To evaluate the nitrate content in the shoot $\left(\mathrm{mg} \mathrm{kg}^{-1}\right)$, four plants were collected randomly before harvest (41 DAE), between 5:30 a.m. and 6:30 a. m., and the nitrate content was determined by the methodology of Cataldo et al. (1975).

At harvest, height $(\mathrm{cm})$, measured from the base to the highest end of the foil, not extended; number of leaves; leaf area ( $\mathrm{cm}^{2}$ per plant), obtained with an electronic meter, brand LI-COR, model 3100; fresh mass of shoot ( $\mathrm{g}$ per plant), determined immediately after harvest by weighing the plants on an electronic scale; and productivity $\left(\mathrm{kg} \mathrm{m}^{-2}\right)$ were evaluated.

Data were submitted to analysis of variance (F-test) using the Agroestat program (BARBOSA; MALDONADO JÚNIOR, 2015). Polynomial regression analysis was performed for $\mathrm{N}$ doses.

\section{RESULTS AND DISCUSSION}

The height was influenced only by the dose of $\mathrm{N}$. The increase in the $\mathrm{N}$ supply resulted in a quadratic adjustment, reaching a maximum height $(27.6 \mathrm{~cm})$ with $198 \mathrm{~kg} \mathrm{~N} \mathrm{ha}^{-1}$ (Figure 1a). Higher doses caused a decrease in plant size. Probably, the overuse of $\mathrm{N}$ fertilizers resulted in the low $\mathrm{N}$ use efficiency and antagonism with other nutrients, thereby affecting the growth of plants, since with the increase of ammonium nitrate application in the treatments with higher $\mathrm{N}$ doses there was an increase in the proportions of $\mathrm{NH}_{4}^{+}$, an element that negatively affects the absorption of other cations $\left(\mathrm{K}^{+}, \mathrm{Mg}^{2+}\right.$ and $\mathrm{Ca}^{2+}$ ) (NASCIMENTO; NASCIMENTO; CECÍLIO FILHO, 2020).

The number of leaves was neither influenced by the treatments, nor did it differ from that in untreated plants. The mean values observed were 13.5 and 10.5 leaves per plant for fertilized and non$\mathrm{N}$ fertilized plants, respectively. The lack of positive effect of $\mathrm{N}$ fertilization may be related to the small plasticity of the characteristic number of leaves, small number of leaves per plant and short cycle of arugula.

The $\mathrm{N}$ dose and number of side-dress applications did not affect leaf area, alone or in an interaction; however, there was a positive response of the $\mathrm{N}$-fertilized arugula in relation to non-N fertilized plants. The observed averages were 504.1 and $355.4 \mathrm{~cm}^{2}$ per plant for $\mathrm{N}$-fertilized and nonfertilized plants, respectively. Unlike the number of leaves, the leaf area had greater plasticity and responded to $\mathrm{N}$ application. Limiting the $\mathrm{N}$ supply has a negative effect on plant growth, since $\mathrm{N}$ is part of the composition of numerous compounds and physiological and biochemical processes essential for plant development (KANT, 2017).

Fresh mass (Figure 1b) and productivity (Figure 1c) were affected by $\mathrm{N}$ doses such that higher applied $\mathrm{N}$ doses resulted in linear increments in both variables. The maximum values were $70.8 \mathrm{~g}$ per plant and $5.5 \mathrm{~kg} \mathrm{~m}^{-2}$ for fresh mass and productivity, respectively. These values were $84 \%$ and $74 \%$ higher than those of plants not fertilized with N. Thus, it can be observed that arugula is highly responsive to $\mathrm{N}$ fertilization. Due to the lack of influence of split $\mathrm{N}$ fertilizer application on the fresh mass and productivity of arugula, it is recommended that the highest dose of $\mathrm{N}$ be supplied, split into two portions at 7 and 14 DAE, because the elimination of one operation contributes economically to the profitability of cultivation. Most likely, the absence of an effect of this factor was due to the very clayey texture of the soil ally with the medium organic matter content, resulting in lower $\mathrm{N}$ leachings (CECÍLIO FILHO et al., 2014; BRAAKHEKKE et al., 2017).

Despite the positive responses observed in the biometric characteristics of arugula, the $\mathrm{N}$ content was not influenced by the treatments. The average values observed were 21.1 and $20.5 \mathrm{~g} \mathrm{~N} \mathrm{~kg}^{-1}$ for plants fertilized and not fertilized with $\mathrm{N}$, respectively. However, plants with different heights and masses can have the same nutrient content, as this corresponds to a relative value.

The nitrate content was influenced by $\mathrm{N}$ doses, and the greater the amount supplied to the arugula plants, the greater the nitrate content (Figure 2 ). The nitrate content obtained with the $\mathrm{N}$ dose that maximized the fresh mass and productivity was $984.11 \mathrm{mg} \mathrm{kg}^{-1}$ and corresponded to an increase of $142 \%$ in relation to the content obtained in non-N fertilized plants. Researchers evaluating other vegetables also observed an increase in the nitrate content in response to the N supply (LIU et al., 2014; BARROS JÚNIOR et al., 2020; SILVA et al., 2021). 

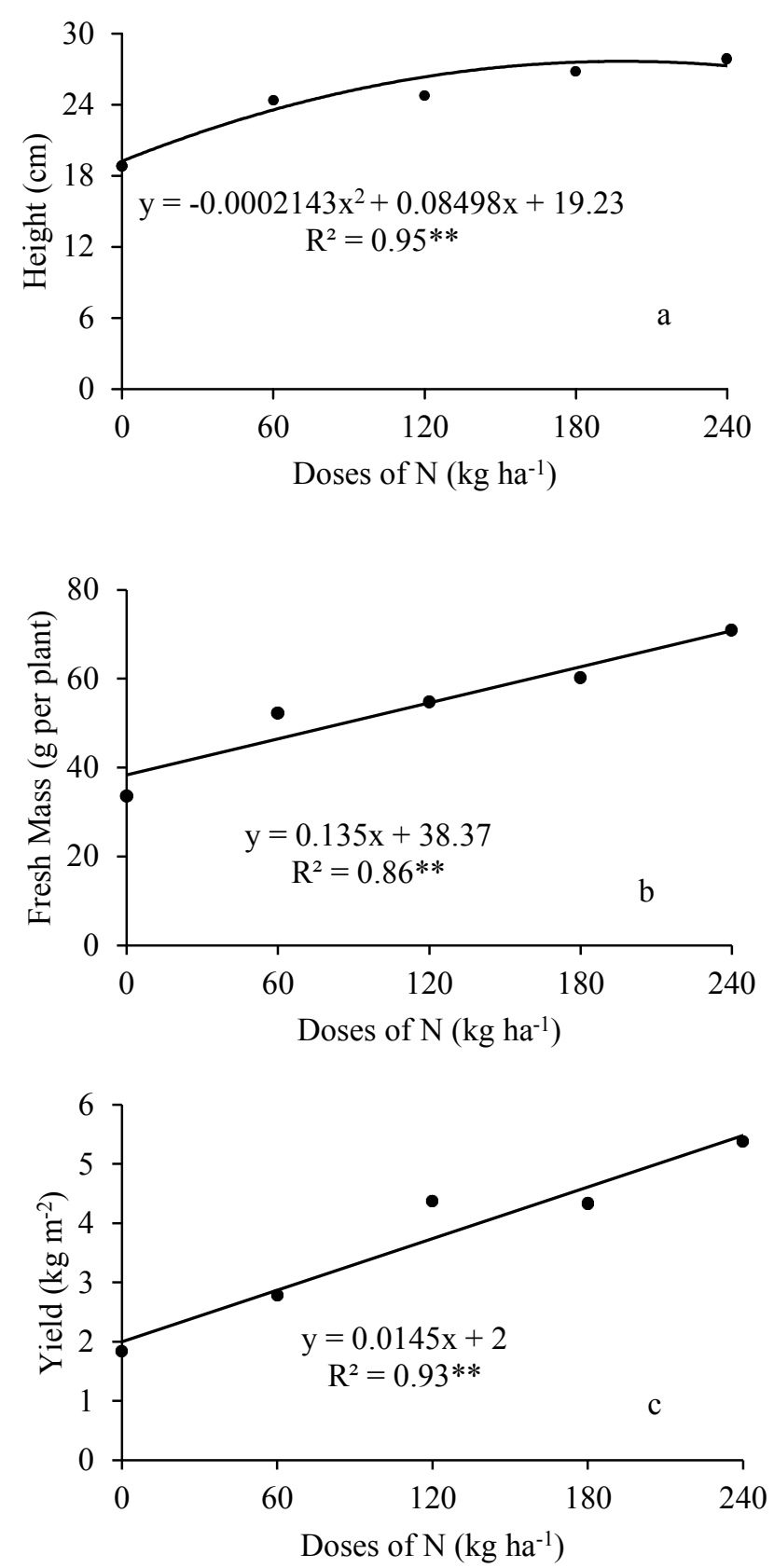

Figure 1. Height (a), fresh weight (b), and productivity (c) of arugula as a function of nitrogen doses.

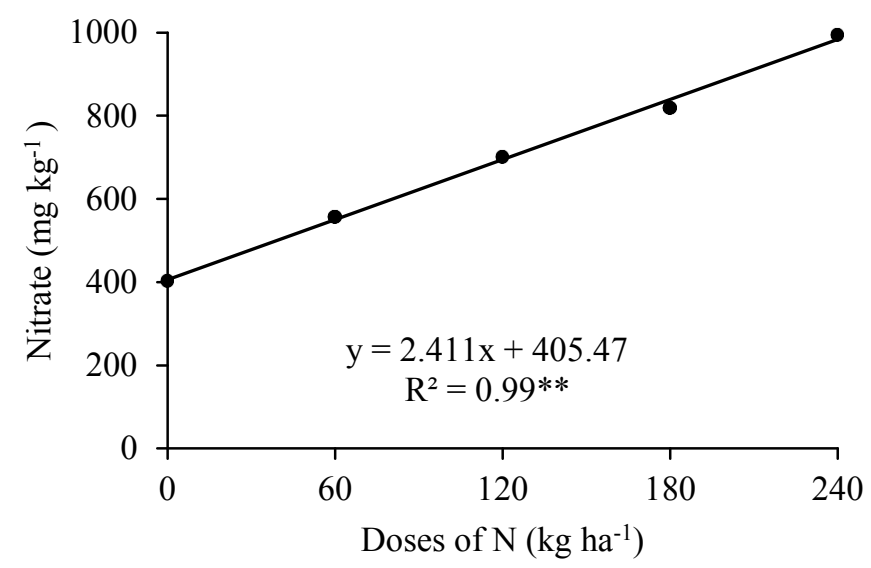

Figure 2. Leaf nitrate content as a function of nitrogen doses. 
Nitrates are the main form of $\mathrm{N}$ found in plants. When present in adequate amounts, nitrate is essential for the biosynthesis of proteins and nucleic acids (DURAZZO et al., 2013). However, when the nitrate availability in the soil is high, and absorption exceeds assimilation by plants, nitrate accumulates in the vacuoles of plant cells (COLLA et al., 2018). It is necessary to keep the nitrate content in arugula plants at adequate levels, since, of the total nitrate ingested by humans, about $70 \%$ comes from fruits and vegetables (UMAR et al., 2013). So, diets rich in nitrate can contribute to the occurrence of methemoglobinemia and endogenous nitrosation, which can cause various types of human cancer (AHMED et al., 2017).

The levels of nitrate observed in this experiment were lower than the maximum limit defined by the European Commission - EC (2011), which allows levels between 6000 and $7000 \mathrm{mg} \mathrm{kg}^{-1}$ for arugula crops. This fact may be related to the cultivation of arugula in the summer. In high light conditions, as in the summer, plants increase the process of photosynthesis, reducing the accumulated nitrate content (CAVAIUOLO; FERRANTE, 2014). So, the nitrate content in arugula leaves was not a qualitative limiting condition for the supply of $\mathrm{N}$, which, as seen by the responses of height, fresh mass and productivity, may still be higher than the doses studied in the present experiment.

\section{CONCLUSION}

The best $\mathrm{N}$ management strategy to improve arugula productivity without increasing the nitrate content to dangerous levels is the supply of $240 \mathrm{~kg} \mathrm{~N} \mathrm{ha}{ }^{-1}$, split into two portions (7 and 14 DAE)

\section{REFERENCES}

AHMED, M. et al. Excessive use of nitrogenous fertilizers: an unawareness causing serious threats to environment and human health. Environmental Science and Pollution Research, 24: 26983-26987, 2017.

ANJANA, A.; UMAR, S. Nitrogenous Fertilizers Boon or Bane? Journal of Plant Science, 2: 106114, 2017.

BARBOSA, J. C.; MALDONADO JÚNIOR, W. Experimentação Agronômica \& AgroEstat: Sistema para análises estatísticas de ensaios agronômicos. 1. ed. Jaboticabal, SP: Gráfica Multipress Ltda, 2015. 396 p.

BARROS JÚNIOR, A. P. et al. Nitrate accumulation in lettuce and rocket in response to nitrogen fertilization in intercropping. Revista Caatinga, 33: 260-265, 2020.

BONASIA, A. et al. Nutritional, biophysical and physiological characteristics of wild rocket genotypes as affected by soilless cultivation system, salinity level of nutrient solution and growing period. Frontiers in Plant Science, 8: 1-15, 2017.

BRAAKHEKKE, M. C. et al. Nitrogen leaching from natural ecosystems under global change: a modelling study. Earth System Dynamics, 8: 1121$1139,2017$.

CATALDO, D. A. L. et al. Rapid colorimetric determination of nitrate in plants tissue by nitration of salicylic acid. Communication in Soil Science and Plant Analysis, 6: 71-80, 1975.

CAVAIUOLO, M.; FERRANTE, A. Nitrates and glucosinolates as strong determinants of nutritional quality in rocket leafy salads. Nutrients, 6: 15191538,2014

CECÍLIO FILHO, A. B. et al. Growing seasons and fractional fertilization for arugula. Comunicata Scientiae, 5: 252-258, 2014.

COLLA, G. et al. Nitrate in fruits and vegetables. Scientia Horticulturae, 237: 221-238, 2018.

DURAZZO, A. et al. Italian Wild Rocket [Diplotaxis Tenuifolia (L.) DC.]: Influence of agricultural practices on antioxidant molecules and on cytotoxicity and antiproliferative effects. Agriculture, 3: 285-298, 2013.

EC - European Commission. Commission Regulation (EC) $\mathrm{N}^{\mathrm{o}}$ 1258/2011 of 2 December 2011 amending Regulation (EC) $\mathrm{N}^{\circ} 1881 / 2006$ as regards maximum levels for nitrates in foodstuffs setting. Official Journal of the European Union, 320: 15$17,2011$.

JASPER, J.; WAGSTAFF, C.; BELL, L. Growth temperature influences postharvest glucosinolate concentrations and hydrolysis product formation in first and second cuts of rocket salad. Postharvest Biology and Technology, 163: 111157, 2020.

KABIR, T. et al. Adjusting Nitrogen Rates with Split Applications: Modelled Effects on N Losses and Profits Across Weather Scenarios. European Journal of Agronomy, 129: 126328, 2021.

KANT, S. Understanding nitrate uptake, signaling and remobilisation for improving plant nitrogen use efficiency. Seminars in Cell \& Developmental 
Biology, 74: 89-96, 2017.

LIU, C. W et al. Effects of Nitrogen Fertilizers on the Growth and Nitrate Content of Lettuce (Lactuca sativa L.). International Journal Environmental Research Public Health, 11: 4427-4440, 2014.

MEN, S. et al. Effects of supplemental nitrogen application on physiological characteristics, dry matter and nitrogen accumulation of winter rapeseed (Brassica napus L.) under waterlogging stress. Scientific Reports, 10: 20201, 2020.

MIYAZAWA, M. et al. Análises químicas de tecido vegetal. In: SILVA, F. C. (Ed.). Manual de análises químicas de solos, plantas e fertilizantes. 2. ed. Brasília, DF: EMBRAPA, 2009. cap. 1, p. 190-223.

MORAIS E. G. et al. Growth and accumulation of macronutrients in arugula. International Journal of Advanced Engineering Research and Science, 7: 176-183, 2020.

NASCIMENTO, C. S.; NASCIMENTO, C. S.; CECÍLIO FILHO, A. B. N:K ratio for phenological growth stages of net melon cultivated in NFT hydroponic system. Revista Caatinga, 33: 108-115, 2020.

NASCIMENTO, C. S.; NASCIMENTO, C. S.; CECÍLIO FILHO, A. B. Economic feasibility of lettuce intercropped with rocket in function of spacing and growing season. Revista Caatinga, 31: 106-116, 2018.

SANTAMARIA, P.; ELIA, A. Producing nitrate-free endive heads: effect of nitrogen form on growth, yield and ion composition of endive. Journal of the American Society for Horticultural Science, 122: 140-145, 1997.

SANTOS, H. G. et al. Sistema brasileiro de classificação de solos. 5. ed. Brasília, DF: EMBRAPA, 2018. 355 p.

SCHIATTONE, M. I. et al. Impact of irrigation regime and nitrogen rate on yield, quality and water use efficiency of wild rocket under greenhouse conditions. Scientia Horticulturae, 229: 182-192, 2018.

SILVA, P. H. S. et al. Nitrogen rates on growth, yield and nitrate foliar content of arugula. Revista Caatinga, 34: 380 - 387, 2021.

TRANI, P. E.; PASSOS, F. A.; AZEVEDO FILHO, J. A. Alface, almeirão, chicória, escarola, rúcula e agrião d'agua. In: RAIJ, B. van et al. (Eds.).
Recomendação de adubação e calagem para o estado de São Paulo (Boletim Técnico, 100). 2. ed. Campinas, SP: Instituto Agronômico, 1997. cap. 18, p. $168-169$.

UMAR, S. et al. Nitrate management approaches in leafy vegetables. In: UMAR, S.; ANJUM, N. A.; KHAN, N. A. (Eds.). Nitrate in Leafy vegetables: Toxicity and safety measures. New Delhi, DL: I.K. International Publishing House Pvt. Ltd, 2013. v. 1, cap. 7 , p. 166-181.

WEIGHTMAN, R. M. et al. Factors influencing tissue nitrate concentration in field-grown wild rocket (Diplotaxis tenuifolia) in southern England. Food Additives \& Contaminants: Part A: Chemistry, Analysis, Control, Exposure \& Risk Assessment, 29: 1425-1435, 2012. 